\title{
EPF as a Marker for Early Embryonic Losses in Repeat Breeders
}

\author{
Satoru YAMAZAKI, Kyoko KAWAHATA ${ }^{1)}$, Taichi GOTO' ${ }^{1)}$, \\ Jutaro TAKAHASHI and Yasuhisa YASUDA
}

Laboratory of Animal Breeding, Faculty of Agriculture, Iwate University, Morioka 020, and ${ }^{1)}$ Technical Research Center, Koiwai Farm Co., Ltd., Shizukuishi, Iwate 020-05, Japan

\begin{abstract}
Early pregnancy factor (EPF) is detectable in sera of pregnant cattle within 24 to $48 \mathrm{~h}$ after fertilization. It has been considered that the repeat breeder is relatively sterile as a result of fertilization failure and the early embryonic loss. This study used the rossete inhibition test to clarify whether repeat breeding is a result of early embyronic loss. We measured serum EPF in cattle that were diagnosed as repeat breeders to examine the incidence of early embryonic losses after artificial insemination (AI) $(n=20)$. There were no significant differences in the presence of $\mathrm{EPF}$ on day 3 after AI for 20 repeat breeders and controls. Furthermore, EPF-positive rates decreased about $60 \%$ by day 21 after AI for both repeat breeders and a control group. It is suggested that a high incidence of early embryonic losses takes place in cattle, and we attempted embryo transfer (ET) as the treatment of choice.

Key words: Early pregnancy factor (EPF), Repeat breeder, Early embryonic losses, Rossete inhibition test, Cattle.
\end{abstract}

(J. Reprod. Dev. 41: 129-132, 1995)

E PF was originally identified by Morton et al. [1] with a modified rossete inhibition test [2]. Rossete inhibition titer (RIT), as defined by Bach et al. [2] is the titer to which an anti-lymphocyte serum (ALS) can inhibit rossete formation between lymphocytes and heterologous erythrocytes to less than $75 \%$ of the number formed in the absence of ALS. EPF has been detected in sera of pregnant cattle [3] within 24 to $48 \mathrm{~h}$ after fertilization, and surgical removal of embryos in sheep is known to result in the disapearance of the EPF within 6 to 48 $h$ [4]. EPF itself has not been isolated for a long time; however, the common usage of the term EPF has implied the existance in pregnancy sera of a unique factor, which is often assumed to be a nov- el, pregnancy-specific protein with the unique capacity to increase RIT $[5,6]$.

The processes of fertilization and implantation are the most important events of viviparous reproduction. It has not been possible to differentiate the failure of fertilization from early embryonic loss in cattle by ultrasonography or progesterone level. However, fetal wastage is thought to be rather frequent. It has been considered that fertilization failure and early embryonic loss occur in the repeat breeder. In this report, we confirmed that EPF is detactable within 3 days after AI or ET. The use of EPF to investigate the incidence of repeat breeding and early embryonic development in cattle is examined. 


\section{Materials and Methods}

We diagnosed 30 Holstein cattle as repeat breeders as follows: (1) they did not continuously in heat; (2) their uterocervical mucous was normal on macroscopy at each estrus; (3) there was no anovulation; and (4) they did not result become pregnant by AI over successive 3 estrus cycles. Cattle which became pregnant by AI (20) or ET (10) during the first cycle after delivery were used as controls. Thirty repeat breeders or controls were divided into 2 groups: Group 1 and Control 1, each consisted of 20 cattle which were inseminataed artificially at natural estrus; Group 2 and Control 2, each consisted of 10 cattle which received transferred embryos. The sources of embryos were 20 in vivo fertilized, 2 fresh, and 8 frozen-thawed in Group 2 and 3 fresh and 7 frozen-thawed in Control 2. Embryos were transferred nonsurgically with a ballon-tip catheter into uterine horn, ispilateral to the ovary bearing the corpus luteum, on day 7 after natural estrus.

Blood was collected on days 3, 6, 12, and 21 after AI or ET. Blood was allowed to clot, and the serum was separated at $2500 \mathrm{rpm}$ for $30 \mathrm{~min}$ and inactivated at $56 \mathrm{C}$ for $30 \mathrm{~min}$. The serum was stored at $-40 \mathrm{C}$.

All samples were evaluated for RIT with the rossete inhibition test described by Ikemizu et al. [7]. ALS was prepared as follows: Ox lymphocytes were isolated with a Ficoll gradient. The lymphocytes were washed 3 times in phosphate buffered saline (PBS) and diluted into $4.0 \times 10^{7}$ cells $/ \mathrm{ml}$. Two Japanese white rabbits were immunized weekly with intravenous (ear vein) injection of cell suspensions $(1.0 \mathrm{ml})$ for 6 weeks. The rabbits were bled 10 days after the last injection, and sera were inactivated at $56 \mathrm{C}$ for $30 \mathrm{~min}$. The ALS was aliquoted into $0.5 \mathrm{ml}$ and stored at $-40 \mathrm{C}$. Guinea pig complement (GPC) was prepared as follows: Blood was collected by cardiac puncture from 2 adult male guinea pigs under anesthesia. The pooled serum was absorbed for $2 \mathrm{~h}$ at $4 \mathrm{C}$, with equal volumes of ox and sheep red blood cells (SRBC) that had been washed 3 times in PBS by centrifugation at $2500 \mathrm{rpm}$ for $5 \mathrm{~min}$. After absorption, the serum was separated at $2500 \mathrm{rpm}$ for $10 \mathrm{~min}$, divided into $0.6 \mathrm{ml}$ aliquots, and stored at - 100 C. SRBC were washed 3 times in PBS by centrifugation at $2500 \mathrm{rpm}$ for $5 \mathrm{~min}$ and diluted to $2.0 \times 10^{8} \mathrm{cell} / \mathrm{ml}$.

For the rossete inhibition test, lymphocytes were separated from peripheral ox blood by Ficoll gradient. The cells were washed 3 times in PBS and diluted to $1.5 \times 10^{7}$ cells $/ \mathrm{ml}$. The lymphocytes $(1.0$ $\mathrm{ml})$ were incubated in sample serum or non-pregnant cow serum $(1.0 \mathrm{ml}$; serum was diluted 1:1 with PBS) at $37 \mathrm{C}$ for $30 \mathrm{~min}$. They were then washed 3 times in PBS and diluted to $1.0 \times 10^{7}$ cells $/ \mathrm{ml}$. The lymphocytes were incubated at $37 \mathrm{C}$ for $90 \mathrm{~min}$ with doubling dilutions of ALS $(0.25 \mathrm{ml}$ extending from $2^{2} \times 10^{2}$ to $2^{5} \times 10^{2}$ cells $\left./ \mathrm{ml}\right)$ in the presence of GPC $(0.05 \mathrm{ml}$; GPC was diluted 1:2 with PBS). After incubation, rossetes were formed by adding SRBC $(0.1 \mathrm{ml})$, and the mixture was centrifuged at $1000 \mathrm{rpm}$ for $5 \mathrm{~min}$ and fixed by $10 \%$ glutaraldehyde $(0.03 \mathrm{ml})$. Finally, $1 \%$ gentian violet $(0.03 \mathrm{ml})$ was added just before observation. The rossetes formed per 1000 lymphocytes were counted. The RIT was recorded as the highest dilution of ALS that caused a 25\% reduction in rossete formation. The results were then compared with the mean of 2 controls without ALS. Dilutions were expressed as $\log _{2}$ reciprocal dilutions of ALS. The RIT $\geqq 4$ was considered EPF-positive. Clinical pregnancy was determined by rectal palpation at 40 days after estrus.

For statistical analysis, the results in Table 1 were compared by chi-square test with Yates' correction and were subjected to 2-way analysis of variance in Table 2.

\section{Results}

Table 1 shows the distribution of EPF-positive and EPF-negative rates. EPF was present in 29 $(72.5 \%)$ out of a total of 40 on day 3 after AI and in $17(85.0 \%)$ out of 20 on day 3 after ET. The incidence of EPF-positive cow sera was $60.0 \%$ in Group $1,85.0 \%$ in Control 1, 70.0\% in Group 2, and 100\% in Control 2. Table 2 indicates the early embryonic losses after AI or ET. The presence of EPF was tested up to 21 days after inception as the rate of EPF-positive /EPF-negative in previous days. There were no significant differences in both Table 1 and Table $2(P>0.05)$. Clinical pregnancy was found in 5 cases out of Group 1, seven out of Control 1, three out of Group 2 (all embryos were frozen-thawed), and 2 out of Control 2 (1 frozen embryo 1 fresh embryo). No pregnancy was found 
Table 1. Distribution of EPF-positive and EPF-negative rates

\begin{tabular}{lccc}
\hline & EPF-positive & EPF-negative & Total \\
\hline AI & & & \\
Group 1 & $12(60.0 \%)^{\mathrm{a}}$ & $8(40.0 \%)$ & 20 \\
Control 1 & $17(85.0 \%)^{\mathrm{a}}$ & $3(15.0 \%)$ & 20 \\
Total & $29(72.5 \%)$ & $11(27.5 \%)$ & 40 \\
\hline ET & & & \\
Group 2 & $7(70.0 \%)^{\mathrm{b}}$ & $3(30.0 \%)$ & 10 \\
Control 2 & $10(100 \%)^{\mathrm{b}}$ & $0(0.0 \%)$ & 10 \\
Total & $17(85.0 \%)$ & $3(15.0 \%)$ & 20 \\
\hline
\end{tabular}

a Values with superscripts were not significantly different $(\mathrm{P}>0.05)$.

$\mathrm{b}$ Values with superscripts were not significantly different $(\mathrm{P}>0.05)$.
Table 2. Early embryonic losses in cattle tested 21 days after AI and ET for the presence of EPF

\begin{tabular}{|c|c|c|c|c|}
\hline & 6 & 12 & 18 & 21(days) \\
\hline \multicolumn{5}{|l|}{ AI } \\
\hline Group $1^{\mathrm{c}}$ & $9 / 12$ & $7 / 9$ & $5 / 7$ & $5 / 5$ \\
\hline Control $1^{c}$ & $10 / 17$ & $9 / 10$ & $9 / 9$ & $8 / 9$ \\
\hline \multicolumn{5}{|l|}{ ET } \\
\hline Group 2d & $7 / 7$ & $7 / 7$ & $3 / 7$ & $3 / 3$ \\
\hline Control $2 \mathrm{~d}$ & $8 / 10$ & $3 / 8$ & $3 / 3$ & $3 / 3$ \\
\hline
\end{tabular}

Data indicates the ratio of EPF positive/EPF positive on the previous test day.

c Values with superscripts were not significantly different $(\mathrm{P}>0.05)$.

$d$ Values with superscripts were not significantly different $(\mathrm{P}>0.05)$.

Table 3. Conception rates and early embryonic losses

\begin{tabular}{|c|c|c|c|c|c|}
\hline & \multirow{2}{*}{$\begin{array}{l}\text { Conception } \\
\text { rate }(\%)\end{array}$} & \multicolumn{3}{|c|}{ Wastage $(\%)$} & \multirow{2}{*}{$\begin{array}{l}\text { Clinical } \\
\text { pregnancy }\end{array}$} \\
\hline & & (a) & (b) & (c) & \\
\hline Group 1 & 60.0 & 41.6 & 16.7 & 58.3 & $41.7(5 / 12)$ \\
\hline Control 1 & 85.0 & 47.0 & 5.9 & 52.9 & $41.1(7 / 17)$ \\
\hline Group 2 & 100 & 30.0 & 40.0 & 70.0 & $30.0(3 / 10)$ \\
\hline Control 2 & 70.0 & 20.0 & 50.0 & 70.0 & $20.0(2 / 10)$ \\
\hline
\end{tabular}

Fetal/embryonic wastage: (a) Within 12 days after AI and ET

(b) From 12 to 21 days after AI and ET

(c) Total

when EPF was negative.

\section{Discussion}

It is known that not all fertilized ova develop into an intact pregnancy. Some embryos disappear at the earliest stages without being noticed: others die later as early clinical abortion. EPF is present in the serum within $48 \mathrm{~h}$ of estimated ovulation and fertilization in humans [8, 9], mice [10] and sheep [11], but it frequently disappears within 14 days. Our AI results are conform with these previous observations. The most important results in this study are listed in Table 3. Clinical pregnancy was about for $40 \%$ for both repeat breeders and controls. Maurer and Chennault [12] reported that $67 \%$ of embryonic death in cattle occurred within 8 days after fertilization. We attemped ET to reduce the early embryonic losses and within 6 days after ET (equivalent to 13 days after estrus) detected the presence of EPF. However, the preg- nancy rate was lower than AI. Mesrogli et al. [9] and Mesrogli and Dieterle [13] reported that early embryonic loss by 6 days after ET is rather frequent in humans and more emphasis should be directed to the correct placement of the embryos. In addition, Diedrich et al. [14] pointed out that stimulation of the cavum uteri by the transfer catheter might release prostaglandins with continuous uterine contraction. Inflammatory factors might contribute to the uterine sensitivity. It also appears that EPF positive serum on day 13 after estrus cannot be assumed to result in a successful pregnancy. We draw the following conclusions from our investigation: (1) not all fertilized ova result in successful pregnancy and, at least in cattle, more than $60 \%$ of the embryos die; and (2) repeat breeders may have problems within 3 days after artificial insemination other than early embryonic loss. Thus, detection of EPF in serum provides a means of monitoring embryonic development. 


\section{References}

1. Morton H, Hegh V, Clunie GJA. Immunosuppression detected in pregnant mice by rossete inhibition test. Nature (Lond) 1974; 249: 459-460.

2. Bach Jf, Antonie B. In vitro detection of immunosuppresive activity of antilymphocyte sera. Nature (Lond) 1968; 217: 658-659.

3. Nancarrow CD, Wallace ALC, Grewal AS. The early pregnancy factor in sheep and cattle. J Reprod Fert (Suppl) 1981; 30: 191-199.

4. Nancarrow CD, Evison BM, Scaramuzzi RJ, Turnbull KE. Detection of induced death of embryos in sheep by the rossete inhibition. I Reprod Fert 1979; 57: 385-389.

5. Clark FM. Identification of molecules and mechanisms involved in the 'Early Pregnancy Factor' System. Reprod Fertil Dev 1992; 4: 423-433.

6. Kathryn T, Julian W, Ian C, Anthony P, Carlos O, Clarke F. Site-directed mutagenesis of human Thioredoxin. J Biol Chem 1993; 30: 22485-22489.

7. Ikemizu Y, Ito K, Kawahata K, Goto T, Takahashi J, Yasuda Y. Study of EPF-like substances detected in fertilized bovine ovum culture medium. J Reprod Dev 1994; 40: 7-11.

8. Barbara E, Rolfe BS. Detection of fetal wastage.
Fertil Steril 1982; 37: 655-660.

9. Mesrogli M, Schneider J, Mass DHA. Early pregnancy factor as a marker for the earliest stages of pregnancy in infertile women. Human Reproduction 1988; 3: 113-115.

10. Morton H, Hegh V, Clunie GJA. Studies of the rossete inhibition test in pregnant mice: eveidence of immunosuppression? Proc R Soc Lond 1976; B193: 413-419.

11. Morton $H$, Nancarrow CD, Scaramuzzi RJ, Evison BM, Clunie GJA. Detection of early pregnancy in sheep by the rossete inhibition test. J Reprod Fertil 1979; 56: 75-80.

12. Maurer RR, Chenault JR. Fertilization failure and embryonic mortality in parous and nonparous beef cattle. J Anim Sci 1983; 56: 1186-1189.

13. Mesrogli M, Dieterle S. Embryonic losses after in vitro fertilization and embryo transfer. Acta Obstet Gynecol Scand 1993; 72: 36-38.

14. Diedrich K, Krebs D, van der Ven H, Pless V. Vervesserung der Implantationsrate nach embryotransfer in einem in-vitrofertilisationsprogramm. Geburtsh u Frauenheilk 1986; 46: 821-824. 